\title{
Mediation of Need for Touch on Factors that Affecting on Online Purchasing Decisions
}

\author{
R Astini \\ Universitas Mercu Buana \\ rina astini@mercubuana.ac.id
}

\begin{abstract}
The purpose of this study is to analyze the factors that influence online purchasing decisions mediated by need for touch (the need to touch). The method used in this research is descriptive quantitative to determine the effect between independent and dependent variables. The respondents used in this study were consumers who bought fashion products on the Vanila Hijab online site in the Jakarta area. The results of this study indicate that price perceptions, trust issues and product attributes do not significantly influence the need for touch and purchasing decisions. While Experience attribute product (familiarity) has a significant and positive effect on need for touch, but has no significant effect on purchasing decisions. Need for touch has a significant effect on purchasing decisions.
\end{abstract}

Keywords: Price Perception, Trust Issue, Product Attributes, Product Attribute Experience, Familiarity, Need for Touch, Purchasing Decisions.

\section{INTRODUCTION}

Touch is one of the five senses that are used to feel a physical condition directly. Product touch is an experience that is felt directly physically between consumers and products [1]. When a consumer touches a product, the consumer gets information about the details or details of the product's material attributes such as texture, temperature, and even weight of the product. Need for Touch or the need to touch a product conceptually is the utilization of information preferences obtained through the haptic system [1]. Along with the rapid development of technology in the current era of Globalization, information can be obtained easily without any restrictions, even consumers are faster in collecting and processing the information they need both for personal consumption and in general, resulting in changes in the behavioral landscape consumers in shopping without direct interaction with products to be purchased through online shopping.

Consumers who buy online cannot judge or evaluate a product physically and intimately. Liu, Batra, and Wang mentioned that people who have a mental representation that is the low haptic information on a product requires more information to assess and evaluate the product itself [2]. Usually this happens to consumers who shop online. Quoting Construal Level Theory by Liu, Brata, and Wang stated that the longer the psychological distance between a person and an object or event (high level) the higher the level of context of abstraction and the closer a person is to the object or event (low level) the more concrete the context is towards the object and event [2]. This shows that 
online shopping allows a consumer to only get product information in an abstract and non-concrete way.

Contrary to this theory, based on a survey of the Indonesian Internet Service Providers Association in 2016 stated that the behavior of Indonesian internet users as many as 84.2 million, had conducted transactions online, while the survey of ICT Indicators on Households and Individuals in 2016, conducted by the Agency for Research and Development of Human Resources (statistika.kominfo.go.id) obtained the classification of products purchased online as many as $73.80 \%$ are fashion products [3].

Based on the data in table 1.1, it is known that the specifications of goods purchased by consumers online at $73.8 \%$ are clothing (fashion) as the type of product most widely purchased compared to other household products. As explained earlier, consumers are prevented from touching products directly when they shop online, whereas fashion is considered a category where haptics play an important role in evaluating products, because the dominant attribute of fashion is texture, such as softness, warmth or flexibility so normally consumers need to touch the fashion product to be purchased to judge whether the product is worth buying or not.

According to the Purchasing Decision theory put forward by Kotler and Armstrong the purchasing process begins with the introduction of needs through physical activity where consumers must at least touch a product for the recognition process which will be a major factor in making purchasing decisions [4]. When consumers shop online, they do not play the role of touch but only rely on abstract mental representations of a product that contradict the Need For Touch theory put forward [1].

Peck and Childers developed and validated the "Need for Touch" scale to measure individual differences in preferences for haptic information consisting of autotelic and instrumental dimensions [1]. The instrumental dimension Need for Touch refers to the aspect of pre-purchase touch that reflects the touch of the final result with a strong purchase goal[1]. Instrumental touches involve consumers who feel confident and satisfied when evaluating the haptic nature of a product called Product Attribute (including; texture, hardness, temperature, or weight) to make an assessment of its functional attributes. Meanwhile, the Autotelic dimension of Need for Touch is related to touch as the final choice in decision making[1]. This form of touch refers to the aspect of product touch sensors with hedonic oriented responses where consumers are only looking for pleasure, passion.

Peck and Childers also stated that differences in touching needs are based on various individuals, products and situations. For preferences, the need for touch is based on motivation, information processing strategies, product expertise, cultural background, search and experience product attributes and Purchase Intention [1].

To understand this phenomenon, researchers conducted a pre-survey of 27 respondents who had shopped fashion products online. This pre-survey is also intended to obtain important variables relating to the need for touch chosen by consumers in making purchases of fashion shopping online. Based on pre-survey result is known that the majority of respondents (75\%) chose the Price Perception, Trust Issue, Product Expertise, Product Attributes, and Experience the Product variables as components that influenced the respondent's need for touch when deciding to buy products both online and offline. The pre-survey results form the basis for determining independent or antecedent variables that will be used in this study. 
Many factors affect consumer confidence in the decision to purchase goods and services, among others: (1) Price perception: an extrinsic factor as a substitute function for quality when customers do not have enough information to know intrinsic attributes so that customers use price perception [4] to estimate quality when only price perception is known; (2) Product quality: Kotler \& Armstrong said that product quality is a potential strategic weapon to defeat competitors [4]. So that if the company has good quality products, it is likely that the company's growth will grow rapidly with the long-term company getting more maximum results; (3) Service Quality: According to Tjiptono in Prabowo and Yulianeu, service quality can be interpreted as an effort to meet the needs and desires of consumers and the accuracy of their delivery in balancing consumer expectations.

Product attributes are factors that buyers consider when buying a product, such as price, quality, packaging, completeness of functions (features), design, after-sales service, and others. Kotler and Armstrong explain that product attributes are the communication of a product to consumers by developing products such as quality, features, and style and design, product quality [5]. According to Kotler and Armstrong the Product Attribute provides a share of the benefits that can be offered [4].

Experience is a product of ongoing transactions that obtain quality, intensity, meaning, and value integrating psychological and emotional conditions [6]. Lundh, L. G. shows that experience is an event or process that can occur spontaneously or voluntarily in everyday situations but always involves internal awareness of something that is happening [7]. Conceptually, every experience comes from interactions between individuals and objects or the environment [8]. Wright and Lynch distinguish between Search Attribute Products and Experience Attribute Products [9]. Product Experience Attributes are more product nuances such as smoothness, softness of a sweater and are ensured only through a touch of the product because it depends on subjective experience. On the other hand, Search Attribute Product is more related to other things such as brand name or color on the sweater that was obtained without any touch on the product

Need for Touch refers to references for handling products before buying [10]. Need for Touch covers two dimensions: autotelic and instrumental. The autotelic need to touch depends on subjective, psychological information and is seen in pleasant emotions (ie pleasant, sensory stimulation, pleasure) that results from touch and uses touch as a means of finding variety. Instrumental touches are goals directed at touch focus, the real nature of hardness, temperature, texture, or weight. Individuals who have a high need for touch play the role of using touch to answer questions during information search and during product evaluation. Lynch et al. show consumers of "high touch" as those who evaluate quality by touching or experience before buying a product and "low-touch" as those who are standard and do not require inspection [11]. For "high touch" products, which online depictions may differ in color and texture from the actual product, traditional brick \& mortar store are preferred because consumers can handle and inspect the product before buying [12]. The need to touch products negatively is related to online purchases, especially for clothing products. Purchases through the Internet and Need for Touch, are negatively correlated [13] One participant did not buy things online was because they could not touch the product. Dissatisfaction with online purchases can be caused by touch, because important tools for evaluating products are lost. When product information is inaccurate, inadequate, or inadequate, as is the case with many online purchases, then the product is more likely to be returned [13]. Preference for handling products before buying influences consumer choice of retail channels [14]. 
Purchasing decisions are part of the buying process that starts with the introduction of needs through feelings [4]. Kotler and Armstrong divide the consumer decision-making process into five stages; problem recognition, information retrieval, alternative evaluations, purchasing decisions, and post-purchase behavior [4]. The general process will usually be carried out in accordance with high requirements when the product or service is first purchased. According to Kotler and Armstrong are several stages of the purchase decision making process, namely: (1) Problem recognition (problem recognition) purchasing process that starts when a buyer realizes a problem or need that is triggered by internal or external stimuli [4]. According to Engel et al. Recognition of problems occurs when consumers are aware of the difference between the existing situation and the expected situation. (2) Information retrieval activities at this stage include speed and breadth in re-generating information in memory and experience. regarding the problem. The information is in the form of beliefs and attitudes that influence consumers towards a strong brand and will be a choice, (3) Alternative evaluation includes comparing information about the brand through the process of tracking evaluation criteria. In this case the consideration of a product is already in the memory of consumers, (4) Purchase Decisions, if the decision taken is to buy, then the buyer will encounter a series of decisions regarding the type of purchase, time of purchase, and how to purchase. At this stage the consumer actually buys the product, (5) post-purchase behavior. After buying a product, consumers will experience some level of satisfaction or perceived dissatisfaction, there is a possibility that the buyer has dissatisfaction after making a purchase because it is not in accordance with the wishes or the previous picture, and so forth.

\section{RESEARCH METHOD}

This research uses causal method to find out about the causal relationship with the Independent Variables (Free) and Dependent Variables (Bound) [15]. To find out the influence of 5 independent variables X1 (Price), X2 (Trust Issues), X3 (Product Expertise), X4 (Product Attributes) and X5 (Experience the Product) on intervening variables Z (Need for Touch) and their implications for the dependent variable Y (Purchase Decision). The population used by the author as a research subject is consumers who buy fashion products on the Vanila Hijab online site in the Jakarta area. The minimum number of samples used in this study were 250 respondents using data collection techniques by distributing questionnaires directly to respondents. The analytical method used in this study uses SEM-LISREL. SEM analysis basically aims to obtain a structural model. In addition, SEM can also be used to see the size of the effect, both direct, indirect and the total effect of the independent variable (Exogenous Variables) on the dependent variable (Endogenous Variables).

\section{RESULTS AND DISCUSSION}

Based on the results of data processing it is known that most respondents have income of 1-5 million, aged 20-30 years, budgeting $>500$ thousand to buy a hijab. This study examines observable indicators of Purchasing Decisions mediated by the Need for Touch variable with a total of 250 respondents. The analysis begins by testing the validity of the data by using the Standardize Loading Factor (SLF) Value. According to Wijayanto a statement item will be considered valid if it has a SLF value $>0.5$ [16]. Based on the results of testing the data in this study indicate that all 
variables have valid values so that the reliability test can be continued, based on data reliability testing, it is known that all reliable variables are used in this study.

After testing the validity and reliability, the next step is to test the suitability of the measurement model. Table 4.1 below are the results of the measurement model match test:

FIGURE 4.1 Measurement Model

TABLE 4.1 Goodness of Fit Table

\begin{tabular}{clccc}
\hline No. & \multicolumn{1}{c}{ GOF Size } & $\begin{array}{c}\text { Target Level } \\
\text { Compatibility }\end{array}$ & $\begin{array}{c}\text { Estimation } \\
\text { Result }\end{array}$ & $\begin{array}{c}\text { Level } \\
\text { Compatibility }\end{array}$ \\
\hline 1 & $\begin{array}{l}\text { Root Mean Square Error of } \\
\text { Appoximation (RMSEA) P } \\
\text { (close Fit) }\end{array}$ & $\begin{array}{c}\text { RMSEA } \leq 0,08 \\
\geq 0,50\end{array}$ & 0,076 & Good Fit \\
2 & Normed Fit Index(NFI) & NFI $\geq 0,90$ & 0,94 & Good Fit \\
3 & $\begin{array}{l}\text { Non-Noormed Fit Index } \\
\text { (NNFI) }\end{array}$ & NNFI $\geq 0,90$ & 0,96 & Good Fit \\
4 & $\begin{array}{l}\text { Comparative Fit Index } \\
\text { (CFI) }\end{array}$ & CFI $\geq 0,90$ & 0,96 & Good Fit \\
5 & $\begin{array}{l}\text { Incremental Fit Index (IFI) } \\
\text { Relative Fit Index (RFI) }\end{array}$ & IFI $\geq 0,90$ & 0,96 & Good Fit \\
7 & $\begin{array}{l}\text { Goodnees of Fit Index } \\
\text { (GFI) }\end{array}$ & GFI $\geq 0,90$ & 0,93 & Good Fit \\
8 & $\begin{array}{l}\text { Adjusted Goodness of Fit } \\
\text { Index (AGFI) }\end{array}$ & AGFI $\geq 0,90$ & 0,77 & Marginal Fit \\
\hline
\end{tabular}

Source : Data Processing by LISREL 8.80

In table 4.1 note that the overall average value indicates a good fit. After obtaining a structural model with good goodness of fit, the next step is to test the structural model (t-value) to test the hypotheses between variables. There are 9 hypotheses in this study as previously described and testing the significance of each variable relationship. The significance value used is 0.05 or $5 \%$ with a $t$ value of $\geq 1.96$ [17]. The estimated value of the causal relationship from the structural model tested by looking at the value of $t$ on the relationship between variables (can be said to have an effect on the value of t-values $\geq 1.96$ ) Figure 4.2 as follows: 


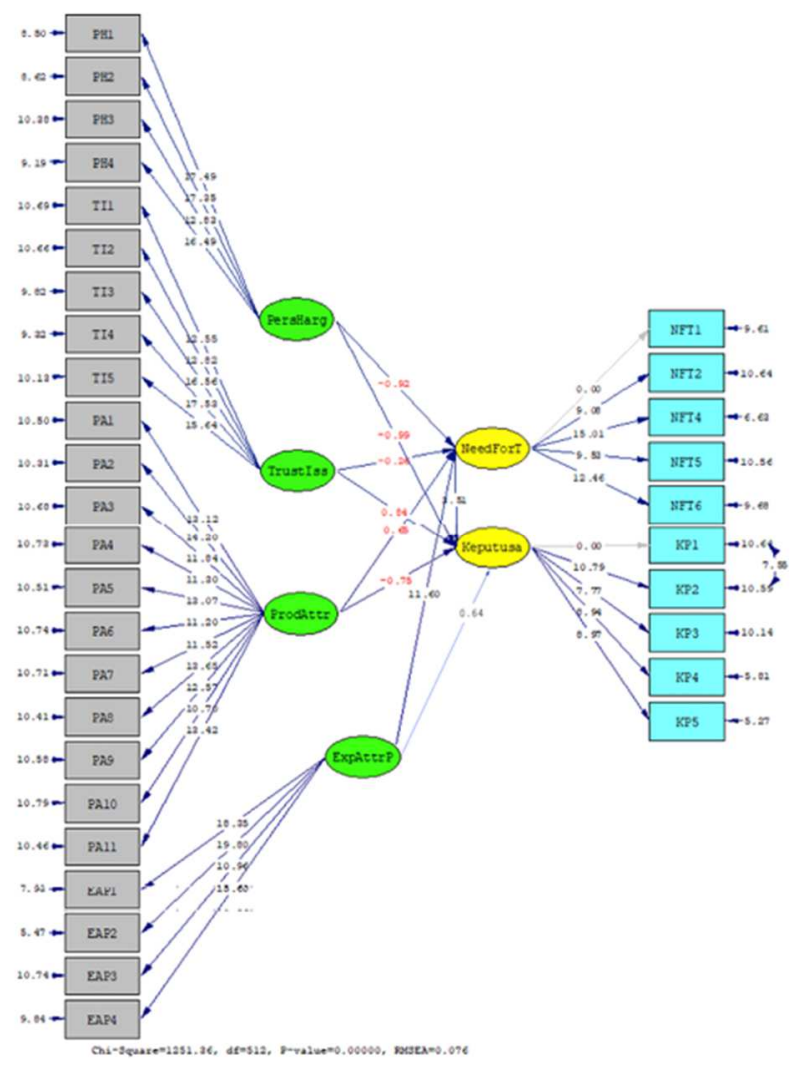

FIGURE 4.2 Struktural Model ( $\mathrm{T}$ - value)

Source : Data Processing by LISREL 8.80

Statistical test results on the research model show that the Experience Attribute Product variable has a positive and significant effect on Need for Touch, while the Need for Touch variable also influences Purchasing Decisions, but the Price Perception, Trust Issue, Product Attribute variables do not affect Need for Touch, and Perception Prices, Trust Issues, Product Attributes, Experience Attribute Products also do not influence purchasing decisions. Thus only two of the nine hypotheses can be accepted.

Based on the result note that Price Perception has no significant effect on Need for Touch. This means that the high and low needs of someone to touch or hold a product (in this case Vanilla Hijab products) are not affected by the perception of the high or low prices of these products.. It could be the second difference between the results of this study because the objects in this study are products purchased online. In line with that, Trust Issue has no significant effect on Need for Touch. This means that the need to touch or hold Vanilla Hijab products is not influenced by consumer 
confidence in the products offered by the company. Disagreement over the results of the study occurred because consumer confidence in a fashion product sold online is not related to the activation of their need to touch the product before deciding to buy. Poduct Attributes also have no significant effect on Need for Touch. This means that the need to touch or hold a product felt by consumers of Vanilla Hijab is not due to the product attributes inherent in the online products offered by Vanilla Hijab. This condition can occur due to: 1) The appearance of the product on the VanilaHijab website has been very good and satisfying so that it does not generate the desire to touch; (2) Online consumers when deciding to buy fashion products do not rule out the need to touch those products. Different from these variables, experience attribute product has a significant effect on Need for Touch. This means that the needs of Vanila Hijab consumers to touch or hold in advance the products offered are influenced by the introduction or familiarity of consumers to the attributes of these products. It can be said the higher the level of recognition the higher the need to touch or hold the product offered, and vice versa.

For independent variables tested the effect on purchasing decisions, Price perception also does not influence online consumer purchasing decisions in this study, means that a consumer who buys Vanilla Hijab products does not base his decision on the perception of the high or low prices of these products. Trust Issue was also analyzed not to have a significant effect on Purchasing Decisions, means that consumer confidence in the quality or brand image of Vanilla Hijab products does not affect their desire to buy or not buy these products. Product attributes also have no significant effect on Purchasing Decisions, means that Vanilla Hijab consumers do not base their decision on buying products offered by the marketplace based on the attributes inherent in those products. Experience Attribute Product has a significant and positive effect on Purchasing Decisions, means that the introduction or familiarity of consumers with the attributes of Vanilla Hijab products is not a factor that causes consumer purchases, and vice versa.

The results of the final analysis are an analysis of the influence of Need for Touch on purchasing decisions which, based on hypothesis testing, it can be said that Need for Touch has a significant positive effect on purchasing decisions. That is, the needs of Vanilla Hijab consumers to touch or hold Vanila Hijab products will cause consumers to become more familiar and familiar with the product. Increasing consumer recognition or familiarity with these products will cause consumers to make purchases or increase the number of purchases.

\section{CONCLUSIONS}

Based on the results of the research discussed earlier, it can be concluded that Price Perception, Trust Issue, and Product attributes do not have a significant effect on Need for Touch, which means the need to touch or hold Vanila Hijab products is not influenced by perceptions of product prices, consumer trust, and product attributes.

Perception of Prices, Trust Issues, and Product attributes does not significantly influence the purchase decision, which means. The decision to buy or not buy Vanila Hijab products is not influenced by product price perceptions, consumer confidence, and product attributes.

Experience Product attributes or consumer familiarity with Vanila Hijab products have a significant effect on Need for Touch. This means that someone's desire to touch the product is influenced by their familiarity with the product. Need for Touch affects purchasing decisions. This 
means that a Vanilla Hijab consumer will decide to buy the products offered if the product can be touched or held.

Suggestions or recommendations that need to be submitted to Vanilla Hijab to make designs of fashion drawings on promotional media that were used more real, designed so that consumers felt as if you had seen a product to be bought directly, because the results of the study concluded that Vanila Hijab consumers wanted the experience of touching or holding the product they were going to buy, the suggestion that could be submitted to Vanila Hijab was to make designs of fashion drawings on promotional media that were used more real, designed so that consumers felt as if you had seen a product to be bought directly.

For further research it is necessary to confirm this variable and add another variable to get the strength of the variable contribution in the research results.

\section{REFERENCES}

[1] J. Peck and T. L. Childers, "To have and to hold: The influence of haptic information on product judgments," J. Mark., vol. 67, no. 2, pp. 35-48, 2003.

[2] W. Liu, R. Batra, and H. Wang, "Product touch and consumers' online and offline buying: the role of mental representation," J. Retail., vol. 93, no. 3, pp. 369-381, 2017.

[3] A. P. Indonesia, “Asosiasi Penyelenggara Jasa Internet Indonesia," Retrieved Novemb., vol. 21, p. 2016, 2015.

[4] P. Kotler and (joint author.) Armstrong Gary M., Principles of Marketing, 15th ed, G. Boston [Massachusetts] : Pearson, 2014.

[5] D. I. Hawkins and D. L. Mothersbaugh, Consumer behavior : building marketing strategy, 12th ed.,. New York : McGraw-Hill Irwin, 2013.

[6] D. C. Mathur, "Naturalistic Philosophies of Experience, Warren H," Green, St. Louis, MO, 1971.

[7] L.-G. LUNDH, "Introspection, consciousness, and human information processing," Scand. J. Psychol., vol. 20, no. 1, pp. 223-238, 1979.

[8] H. Li, T. Daugherty, and F. Biocca, "Characteristics of virtual experience in electronic commerce: A protocol analysis,” J. Interact. Mark., vol. 15, no. 3, pp. 13-30, 2001.

[9] A. A. Wright and J. G. Lynch Jr, "Communication effects of advertising versus direct experience when both search and experience attributes are present," J. Consum. Res., vol. 21, no. 4, pp. 708-718, 1995.

[10] C. Spence and A. Gallace, "Multisensory design: Reaching out to touch the consumer," Psychol. Mark., vol. 28, no. 3, pp. 267-308, 2011.

[11] M. J. Brimecombe, F. A. De Leij, and J. M. Lynch, "The effect of root exudates on rhizosphere microbial populations," in The rhizosphere, CRC Press, 2000, pp. 111-156.

[12] J. Webster, R. Balasubramanian, and R. Peter, "An investigation of retailer perception apparel sizing issues," in Proceedings of the 2nd Biennial Conference of the Academy of World Business, Marketing and Management Development, 2006, pp. 918-926.

[13] J. D. Quick et al., "Managing drug supply: the selection, procurement, distribution, and use of pharmaceuticals," 1997.

[14] A. M. Levin, I. R. Levin, and C. E. Heath, "Product category dependent consumer preferences for online and offline shopping features and their influence on multi-channel 
retail alliances.," J. Electron. Commer. Res., vol. 4, no. 3, pp. 85-93, 2003.

[15] Sugiyono, Metode penelitian pendidikan:(pendekatan kuantitatif, kualitatif dan $R \& D$ ). Alfabeta, 2008.

[16] S. H. Wijayanto, "Structural equation modeling dengan LISREL 8.8: Konsep \& Tutorial," Yogyakarta Graha Ilmu, 2008.

[17] R. Tadei, "Spatial interaction theory and planning models: Anders KARLQVIST, Lars LUNDQVIST, Folke SNICKARS and Jörgen W. WEIBULL (Eds.) Volume 3 in: Studies in Regional Science and Urban Economics North-Holland, Amsterdam, 1978, x+ 388 pages, Dfl. 95." North-Holland, 1980. 